\title{
Stany Zjednoczone a integracja polityczna, militarna i gospodarcza Europy Zachodniej w pierwszych latach po II wojnie światowej (do 1950 r.). Ameryka nadaje ton i dyktuje warunki (Część I)
}

\author{
The United States and the Political, \\ Military and Economic Integration of Western Europe \\ in the First Years after the Second World War (Until 1950). \\ America Sets the Tone and Dictates the Conditions (Part 1.)
}

\section{- Abstrakt •}

Wpływ USA na formy i przebieg procesów integracyjnych Europy Zachodniej był bardzo silny, zwłaszcza w pierwszych latach powojennych. Był to wpływ siły zewnętrznej, która będąc poza wewnętrznymi sprzecznościami interesów Europy Zachodniej, dysponowała realnymi możliwościami narzucania korzystnych dla siebie koncepcji integracyjnych. Integracja owa była w tym okresie zgodna zarówno z interesami gospodarczymi, jak i militarnymi USA. Głównymi przyczynami skłaniającymi kraje zachodnioeuropejskie w pierwszych latach powojennych do akceptacji sugerowanych przez Stany Zjednoczone rozwiązań były: trudna sytuacja gospodarcza w tych krajach, obawa przed dojściem do władzy partii komunistycznych oraz niechętna (wroga) postawa wobec ZSRR i tworzącego się bloku komunistycznego. Kompleks tych przyczyn spowodował czasowe zneutralizowanie tendencji odśrodkowych oraz wyciszenie rozbieżności interesów między poszczególnymi krajami Europy Zachodniej. Te motywy integracyjne wpłynęły również na

\section{- Abstract •}

The influence of the US on the forms and course of the integration processes in Western Europe was very strong, especially in the first post-war years. It was the influence of an external force which, being free of the internal contradictions stemming from Western Europe's interests, had at its disposal real capabilities to impose integration concepts beneficial to itself. Such integration was in line with both the economic and military interests of the United States during this period. The main reasons prompting Western European countries in the first post-war years to accept the solutions suggested by the United States were: the said countries' difficult economic situation, fear of the communist parties' coming to power, and the reluctant (hostile) attitude towards the USSR and the communist bloc. The combination of these causes served to temporarily neutralize the centrifugal tendencies and muted the divergence of interests between the individual countries of Western Europe. Such motives of integration also influenced the character of the emerging West- 
ukształtowanie się charakteru powstających zachodnioeuropejskich organizacji politycznych, militarnych i gospodarczych. Rozwój gospodarczy krajów zachodnioeuropejskich, którego źródeł oprócz Planu Marshalla należy dopatrywać się w innych czynnikach, prowadził w późniejszym okresie do przesunięcia inicjatyw integracyjnych ze strony amerykańskiej na stronę europejską. $Z$ formalnego punktu widzenia efektami polityki Stanów Zjednoczonych w okresie do 1950 r. były: powołanie do życia NATO, utworzenie OEEC oraz doprowadzenie do podpisania układu o EUP.

Słowa kluczowe: II wojna światowa; okres powojenny; Europa Zachodnia; Stany Zjednoczone; integracja polityczna, militarna i ekonomiczna; doktryna izolacjonizmu; organizacje zachodnioeuropejskie; rozwój gospodarczy; handel międzynarodowy; pożyczki i kredyty; Plan Marshalla ern European political, military and economic organizations. The economic development of Western European countries, whose sources, in addition to the Marshall Plan, should be seen also in other factors, later led to a shift of integration initiatives from the American side to the European one. From a formal point of view, the effects of US policy in the period up to 1950 entailed: the establishment of NATO, the creation of the OEEC and the signing of the agreement on the EUP.

Keywords: Second World War; post-war period; Western Europe; United States; political, military and economic integration; the doctrine of isolationism; Western European organizations; economic development; international trade; loans and credits; Marshall Plan

\section{Wstęp}

Ze względu na jeden aspekt tego zagadnienia, a mianowicie stosunek USA do koncepcji integracyjnych Europy Zachodniej, zatrzymamy się głównie nad rozwojem tej idei po II wojnie światowej, wracając do przeszłości tylko po to, aby lepiej uwypuklić cechy charakterystyczne interesującego nas problemu. Właśnie z tego względu inspirujące jest prześledzenie ewolucji polityki Stanów Zjednoczonych wobec reszty świata, w tym szczególnie wobec Europy Zachodniej (Bulletin, 1956). Historycy zachodnioeuropejscy oraz amerykańscy podkreślają przełomowe znaczenie dwu wydarzeń w życiu politycznym USA: przemówienia G. Waszyngtona (Farewell Address) w dniu 17 września 1796 r. oraz przemówienia H. Trumana z 12 marca 1947 r. W obu wystąpieniach sformułowano zasady amerykańskiej polityki zagranicznej, według których Stany Zjednoczone powinny układać swoje stosunki polityczne z resztą świata, w tym głównie z Europą (Beloff, 1963). Pierwsze przemówienie (którego rozwinięciem było hasło: Ameryka dla Amerykanów), sformułowane zostało przez Monroego w 1923 r. i zapoczątkowało realizację doktryny izolacjonizmu. Drugie natomiast oficjalnie potwierdzało totalne i ciągłe zaangażowanie się USA w sprawy polityki światowej oraz politykę mocarstwową w skali globalnej Porównajmy najważniejsze myśli zawarte w obu tych wystąpieniach (Urwin, 1995). 
W Farewell Address G. Waszyngton stwierdził: „Europa posiada własne interesy, które z naszymi nie mają żadnych lub prawie żadnych związków. Dlatego musi ona być uwikłana w ciągłe kontrowersje, których przyczyny są dla nas obojętne. (...) Naszą słuszną polityką powinno być uwikłanie stałych aliansów z każdą częścią reszty świata. Zapewniając własne bezpieczeństwo przez odpowiednie posunięcia mające cechy defensywne, możemy wierzyć w skuteczność czasowych przymierzy powodowanych nadzwyczajnymi niebezpieczeństwami” (Morison, 1928, s. 202). Przemawiając z kolei na forum Kongresu w 1947 r., H. Truman sformułował następująco dalszą rolę USA w świecie i przyczyny, które skłoniły je do całkowitego przekreślenia doktryny izolacjonizmu: „Jednym z podstawowych celów polityki zagranicznej Stanów Zjednoczonych jest stworzenie warunków, w których my i inne narody będziemy mogli żyć wolni od przemocy. Wierzę, że polityką Stanów Zjednoczonych musi być popieranie wolnych ludzi, którzy cierpią prześladowania ze strony uzbrojonych mniejszości lub presji zewnętrznych. (...) Wolni ludzie na całym świecie oczekują od nas poparcia w zachowaniu ich wolności. Jeśli stracimy wiarę w nasze przodownictwo (leadership), możemy narazić na niebezpieczeństwo pokój światowy - i z pewnością narazimy na niebezpieczeństwo dobrobyt (welfare) naszego kraju" (In Quest od Peace, 1951, s. 88).

W praktyce obrona „wolnego świata” oznaczała aktywny antykomunizm zarówno w polityce zagranicznej, jak i wewnętrznej, walkę z „postępowymi” siłami na całym świecie i realizację wielkomocarstwowych interesów USA. W publikacjach zachodnich z upodobaniem podnoszona była bezinteresowność Stanów Zjednoczonych w ich polityce zagranicznej i teza, że to ogólna sytuacja światowa zmusiła je do rewolucyjnych jakoby zmian w polityce zagranicznej (Beugel, 1966). Bliższe jednakże przyjrzenie się polityce zagranicznej USA pokazuje, że w rzeczywistości polityka izolacjonizmu i polityka globalnego zaangażowania stanowiły przejaw umiejętnego wykorzystania sytuacji zewnętrznej i wewnętrznej w celu wzrostu potęgi i bogactwa USA bez oglądania się na interesy innych państw, nawet sojuszników. Polityka izolacjonizmu oznaczała politykę ekspansji, najpierw w granicach, w jakich ukształtowały się obecne Stany Zjednoczone, a następnie w skali kontynentu. Była to ekspansja zarówno terytorialna, jak i gospodarcza. Doktryna Trumana oznaczała rozciągnięcie jej na cały świat (Ferrell, 1996). Stany Zjednoczone wskutek dwu wojen światowych wzmocniły swoją pozycję gospodarczą i militarną na tyle, aby pretendować do roli supermocarstwa. 


\section{Pozycja polityczna i gospodarcza USA w okresie do II wojny światowej}

„Izolacjonizm” USA można było odnieść właściwie do stosunków z Europą. Z bardzo praktycznych względów izolacjonizm ten był na rękę kapitałowi amerykańskiemu. Zapewniał mu ekspansję zarówno polityczną, jak i gospodarczą w skali kontynentu. Wystarczy porównać obszar Stanów Zjednoczonych w 1790 r. (2302 tys. $\mathrm{km}^{2}$ ) z obszarem w 1950 r. (7828 tys. $\left.\mathrm{km}^{2}\right)$, aby uzmysłowić sobie zakres ekspansji terytorialnej. Nie było to tylko pokojowe zasiedlanie wschodnich obszarów Stanów Zjednoczonych. W 1848 r. w wyniku wojny ze Stanami Zjednoczonymi Meksyk utracił prawie połowę swego terytorium, w tym Kalifornię. W 1846 r. Stany Zjednoczone zmieniły granicę z Kanadą, przyłączając nowe terytoria, a w 1867 r. nabyły od Rosji Alaskę. W 1868 r. USA anektowały Wyspy Hawajskie i w wyniku wojny z Hiszpanią podporządkowały sobie Kubę. Uzyskały ponadto Puerto Rico oraz Filipiny. Przyczyniając się do sztucznego utworzenia Panamy w 1903 r., USA uzyskały kontrolę nad strefą Kanału Panamskiego. Jednocześnie wzmagała się penetracja kapitału amerykańskiego w Ameryce Południowej (Rutkowski, 1972). Nie rozwijając szerzej tego tematu, można stwierdzić, że polityka izolacjonizmu, uznając dominującą rolę Wielkiej Brytanii w XIX w., położyła podwaliny pod supremację Stanów Zjednoczonych na kontynencie amerykańskim oraz stworzyła podstawy gospodarcze do ekspansji zamorskiej.

W pierwszych latach XX w. zaistniały już warunki do zmiany dotychczasowego kursu polityki zagranicznej USA. Stany Zjednoczone wzięły udział w końcowym etapie I wojny światowej, a także interesowała je powojenna sytuacja w Europie. Jednak konsekwentnie przez wiele lat realizowana doktryna izolacjonizmu nie pozwoliła na szybki zwrot w kierunku nowej polityki państwa, które stało się już wielkim mocarstwem przemysłowym. W 1920 r. USA nie przystąpiły do Ligi Narodów, co świadczyło o utrzymywaniu się tendencji niezaangażowania. W Europie wstrząs, jakim była I wojna światowa, i duże zmiany w układzie sił między państwami oraz powstanie ZSRR stały się czynnikami ożywiającymi dyskusje nad przyszłością Europy oraz nad drogami prowadzącymi do jej jedności politycznej i gospodarczej. Ten kierunek myślenia zaowocował inicjatywami dyplomatycznymi oraz powstaniem organizacji popierających ideę integracji Europy (Kwilecki, 1969). Żadna z tych inicjatyw nie weszła w stadium realizacji, ponieważ sprzeczności między państwami europejskimi (zwłaszcza Wielką Brytanią a i resztą Europy) były zbyt silne, aby można było wprowadzić je w czyn. Dlatego też stosunek Stanów Zjednoczonych do idei integracyjnych można odczytywać jedynie pośrednio, biorąc głównie pod uwagę fakt, iż Stany Zjednoczone nie weszły do Ligi Narodów 
(Stebbins, 1950). Pozostając poza Ligą Narodów, Stany Zjednoczone zamanifestowały swój niechętny wówczas stosunek do instytucji mogących przekształcić się w instytucje ponadpaństwowe. Podobnie niechętnie zareagowały na Plan Brianda, uważając, że był wymierzony m.in. przeciwko Ameryce.

Plan Brianda, nazwany tak od nazwiska francuskiego premiera Aristide'a Brianda i wysunięty przez niego na forum Ligi Narodów w 1929 r., przewidywał utworzenie Konfederacji Europejskiej kierowanej przez sekretariat i komitet polityczny. „Celem ostatecznym miał być luźny związek, sui generis respektujący suwerenność państw wchodzących w jego skład. Związek kierowałby się trzema kardynalnymi zasadami, a mianowicie: 1) podporządkowaniem problemów ekonomicznych zagadnieniu politycznemu, co miało zapobiec hegemonii ze strony państwa o największym potencjale gospodarczym; 2) uznaniem, że europejska współpraca polityczna winna dążyć do zbudowania takiego związku, który przynosząc wszystkie korzyści, płynące ze zbiorowej solidarności, respektowałby w pełni suwerenność gospodarczą każdego państwa; 3) zbliżeniem systemów gospodarczych europejskich pod ścisłą kontrolą poszczególnych rządów" (Wandycz, Frendl, 1965, s. 46). Plan Brianda spotkał się z krytyką pośród samych krajów europejskich, w tym głównie Wielkiej Brytanii, stojącej na czele imperium pozaeuropejskiego, i nie był inicjatywą, w stosunku do której Stany Zjednoczone musiałyby bardziej precyzyjnie określić swoje stanowisko.

Inną z inicjatyw okresu międzywojennego zmierzających w kierunku popularyzacji i propagowania koncepcji federalizmu europejskiego był ruch paneuropejski kierowany przez hr. Coudenhove-Kalergiego. Jednakże żadna z tych międzywojennych koncepcji nie wyszła poza sferę dyskusji teoretycznych. Na jeszcze jeden aspekt tych koncepcji warto zwrócić uwagę, a mianowicie na to, że miały one wyraźnie antysowiecki charakter. Europa zintegrowana politycznie i gospodarczo była w nich traktowana jako przeciwwaga ZSRR.

Już w trakcie II wojny światowej Stany Zjednoczone zmieniły swoje nastawienie wobec organizacji międzynarodowych o charakterze politycznym i gospodarczym (Morawiecki, 1970). Świadczyła o tym akceptacja przez USA koncepcji ONZ oraz powołanie na mocy układów z Bretton Woods międzynarodowych organizacji o charakterze gospodarczym działających pod silnym ich wpływem (Kamecki, Sołdaczuk, Sierpiński, 1964, s. 145). Instytucjami powołanymi na mocy tych układów były Międzynarodowy Bank Odbudowy i Rozwoju oraz Międzynarodowy Fundusz Walutowy. Stosunek USA do tych organizacji świadczył o zasadniczej zmianie stanowiska wobec koncepcji integracyjnych (Harper, 1994). Jednocześnie stanowisko USA było wyrazem tego, że w czasie wojny dawały one priorytet „rozwiązaniom ogólnym jako lepiej odpowiadającym interesom 
amerykańskiego ekspansjonizmu”. Z tych względów USA niechętnie odnosiły się do brytyjskiej propozycji utworzenia organizacji państw europejskich w ramach federacji regionalnych wysuniętych przez ministra spraw zagranicznych Wielkiej Brytanii Edena na moskiewskiej konferencji w 1943 r. Doświadczenie powojenne wykazało, że takie organizacje jak MFW i MBOiR nie spełniły zadania ustabilizowania gospodarek krajów zachodnioeuropejskich i poprawienia ich bilansów płatniczych (Spanier, 1960). Nadzieja, że instytucje te będą efektywnym narzędziem uzdrawiającym międzynarodowe stosunki ekonomiczne w ramach gospodarki światowej, nie znalazła potwierdzenia i Stany Zjednoczone musiały szukać innych rozwiązań zmierzających do umocnienia ich potęgi w świecie i do przezwyciężenia dwu przeszkód na drodze swojego ekspansjonizmu: trudności, jakie przeżywały gospodarki kapitalistyczne i wzrostu znaczenia sił „postępowych” na świecie. Rozwiązaniem takim, w którym USA zaprezentowały swój nowy punkt widzenia na współpracę polityczną i gospodarczą państw Europy Zachodniej, był Plan Marshalla (Lundestad, 1998). Plan Marshalla był próbą przezwyciężenia kryzysu i wynikiem zmian w pozycji politycznej i gospodarczej Stanów Zjednoczonych wobec Europy Zachodniej oraz w układzie sił między blokiem zachodnim a blokiem komunistycznym na korzyść tego pierwszego.

\section{Miejsce USA w gospodarce światowej przed II wojną światową}

Rozwój w pełni samowystarczalnej gospodarki amerykańskiej w XIX w. był możliwy dzięki specyficznym warunkom powstałym w tym okresie w Stanach Zjednoczonych, a mianowicie dzięki napływowi taniej siły roboczej i kapitałów z Europy, a także dzięki bogactwom naturalnym i żyznym ziemiom, co umożliwiło wzrost produkcji rolnej i przemysłowej uniezależnionej od importu. W $1870 \mathrm{r}$. udział USA w światowej produkcji przemysłowej wynosił 23,3\%, ustępując jedynie Wielkiej Brytanii, wytwarzającej w tym czasie 31,8\% światowej produkcji. Jednak już w 1913 r. USA osiągnęły poziom 35,8\% światowej produkcji, prześcigając w ten sposób wszystkie potęgi świata (Nowak, 1965, s. 179).

Z I wojny światowej państwa europejskie wyszły obciążone poważnymi zobowiązaniami finansowymi wobec Stanów Zjednoczonych, co nie było obojętne dla dalszej polityki Europy wobec tego kraju. Zadłużenia te narosły już przed I wojną światową. Dłużnikami USA stały się kraje eksportujące przede wszystkim surowce i płody rolne. Nie znajdując zbytu na swoje produkty na rynkach Stanów Zjednoczonych, kraje te zadłużały się z powodu niemożliwości zdobycia dewiz niezbędnych do pokrycia importu przemysłowego. Wojna światowa stwo- 
rzyła dodatkowo doskonałe warunki dla rozwoju przemysłu amerykańskiego i dla rozszerzenia działalności inwestycyjnej USA za granicą. Zagraniczne lokaty długoterminowe wzrosły do 6,5 mld dol. w 1929 r., co stanowiło czteromiliardowy wzrost w sześcioletnim okresie (od 1914 r.; Łychowski, 1954, s. 155).

Po I wojnie światowej USA stały się głównym wierzycielem świata kapitalistycznego. Procentowy udział w światowej produkcji przetwórczej wzrósł z 35,8\% w 1913 r. do 42,2\% w latach 1926-1929, natomiast udział w światowym eksporcie przemysłu przetwórczego powiększył się z 12,6\% w 1913 r. do 19,6\% w 1937 r. (Ellsworth, 1958, s. 414). Wierzytelności Stanów Zjednoczonych osiągnęły w 1930 r. poziom 8,8 mld dol. (Fisher, 1945, s. 253) W 1930 r. uchwalono w USA nową, protekcyjną taryfę celną (Hawley-Smoot Tariff) oraz zdewaluowano dolara. Zamiast więc wstrzymania rosnącego zadłużenia przez odpowiedni wzrost importu dóbr i usług świat kapitalistyczny został zmuszony do spłaty zobowiązań w dewizach i w złocie. Pozycja Stanów Zjednoczonych umacniała się coraz bardziej, a ich przodująca rola w gospodarce światowej stawała się oczywista. Już w latach międzywojennych stało się to powodem silnych napięć między krajami europejskimi a USA (Feld, 1968).

Jednym z najbardziej syntetycznych wskaźników wzrostu gospodarczego jest tempo wzrostu produktu narodowego brutto (PNB). Dane zawarte w poniższej tabeli wskazują wyraźnie, iż porównanie tempa wzrostu PNB Stanów Zjednoczonych w pierwszej połowie XX w. z tempem wzrostu PNB wysoko rozwiniętych kapitalistycznych krajów europejskich wypadało na korzyść USA. Biorąc pod uwagę skalę gospodarki amerykańskiej, widać, że dynamika rozwoju gospodarczego (mimo kryzysu w latach 1929-1933) stanowiła solidną podstawę wzrostu politycznego znaczenia USA wśród krajów wysoko rozwiniętych.

Tabela 1. Tempo wzrostu PNB w wybranych krajach zachodnich w latach 1913-1959 (średnioroczne tempo wzrostu w cenach stałych)

\begin{tabular}{|l|c|c|c|c|c|}
\hline Kraj & $\mathbf{1 9 2 3 - 1 9 2 9}$ & $\mathbf{1 9 2 9 - 1 9 3 9}$ & $\mathbf{1 9 3 9 - 1 9 4 9}$ & $\mathbf{1 9 4 9 - 1 9 5 9}$ & $\mathbf{1 9 1 3 - 1 9 5 6}$ \\
\hline USA & 3,3 & 0,6 & 4,4 & 3,3 & 3,2 \\
Francja & 5,5 & $-1,1$ & 0,2 & 4,5 & 1,3 \\
RFN & 3,5 & 4,3 & $-2,2$ & 7,4 & 2,1 \\
Włochy & 2,4 & 1,6 & 0,1 & 5,9 & 1,9 \\
Holandia & 4,0 & 0,4 & 2,3 & 4,8 & 2,6 \\
Belgia & 4,0 & $-0,2$ & 0,6 & 3,0 & 1,6 \\
Wielka Brytania & 2,9 & 2,2 & 1,0 & 2,4 & 1,6 \\
Szwecja & 4,2 & 3,0 & 3,0 & 3,4 & 2,4 \\
Szwajcaria & 5,1 & $-0,1$ & 1,5 & 5,2 & 3,1 \\
\hline
\end{tabular}

Źródło: Economic Survey of Europe in 1961, Part 2: Some Factors in Economic Growth in Europe during the 1950 s, s. 3 . 


\section{Wpływ II wojny światowej na zmianę pozycji gospodarczej i politycznej Stanów Zjednoczonych w świecie}

Stany Zjednoczone były jedynym państwem z większych krajów kapitalistycznych, które nie ucierpiało gospodarczo wskutek wojny, a wręcz przeciwnie - zyskało na niej, stając się światowym mocarstwem, potentatem przemysłowym i finansowym. W momencie wybuchu wojny USA zajmowały pozycję neutralną (Bulletin, 1950). Pomimo to sprzyjały państwom alianckim, dostarczając im wiele materiałów potrzebnych do prowadzenia działań zbrojnych. Wielkie inwestycje, które były finansowane przez rząd amerykański dla zwiększenia produkcji zbrojeniowej, przyczyniły się do wzrostu zatrudnienia i podniosły zdolność produkcyjną przemysłu i rolnictwa (Camps, 1957). W okresie koniunktury wojennej produkt narodowy USA wzrósł ponaddwukrotnie. Było to możliwe dzięki charakterowi produkcji amerykańskiej, która skierowana była w tym czasie na zyski wojenne ( $Z$ zagadnień dojrzewania kryzysu, 1954).

W latach 1941-1945 USA wydały z budżetu państwowego na zbrojenia i gospodarkę wojenną $275 \mathrm{mld}$ dol. (ok. 52\% łącznego czteroletniego produktu narodowego). Środki na ten cel zostały zdobyte głównie przez emisję pożyczek wewnętrznych. W 1945 r. wewnętrzny dług publiczny wynosił w USA 237 mld dol. wobec 41 mld dol. w 1939 r. (Łychowski, 1954, s. 288). Produkcja wojenna osiągnęła punkt szczytowy w roku 1943. Wtedy to poziom wskaźnika produkcji przemysłowej był wyższy o $125 \%$ od poziomu przedwojennego. Rozwinięta do dużych rozmiarów produkcja przemysłowa wymagała kontynuacji w latach powojennych, ponieważ zahamowanie produkcji równałoby się wielkim stratom w zainwestowanych mocach produkcyjnych i olbrzymiemu wzrostowi bezrobocia. Dlatego też USA usiłowały już w czasie trwającej koniunktury wojennej zapewnić sobie chłonne rynki zbytu na okres po II wojnie światowej, a eksport podnieść do takiego poziomu, aby mógł on odegrać rolę poważnego czynnika w utrzymaniu amerykańskiej koniunktury wewnętrznej na stosunkowo wysokim poziomie (World Economic Survey, 1955).

$\mathrm{Na}$ podstawie ocen produktu narodowego Stanów Zjednoczonych można stwierdzić, że w latach 1929-1938 eksport amerykański wynosił przeciętnie nie więcej niż 3,9\% produktu narodowego, co stanowiło ok. 2,3 mld dol. W okresie pięciolecia 1941-1945 przeciętna roczna wartość eksportu amerykańskiego wzrosła do 10 mld dol., co stanowiło ponad 5\% w stosunku do zwiększonego produktu narodowego ( $Z$ zagadnień dojrzewania kryzysu, 1954, s. 148). Warto się zastanowić, w jaki sposób olbrzymi wzrost amerykańskiego eksportu do krajów Europy Zachodniej mógł być w ciężkich powojennych warunkach sfinansowany. Tabela 
poniżej zawiera dane o wielkości importu i eksportu towarów i usług przed II wojną światową i w okresie pierwszych lat po wojnie.

Tabela 2. Import, eksport oraz saldo bilansu handlowego USA w wybranych latach (w mld dol.)

\begin{tabular}{|l|c|c|c|}
\hline Lata & Import & Eksport & Saldo bilansu handlowego \\
\hline $1936-1938$ & 3,6 & 4,1 & $+0,5$ \\
1946 & 7,2 & 15,0 & $+7,8$ \\
1947 & 8,5 & 19,7 & $+11,2$ \\
\hline
\end{tabular}

Źródło: T. Łychowski, 1954, s. 328.

$\mathrm{Z}$ danych wynika, iż dodatnie saldo bilansu handlowego wynosiło w latach 1946-1947 ok. 19 mld dol. Zostało ono sfinansowane w sposób następujący:

Tabela 3. Źródła finansowania bilansu handlowego w latach 1946-1947 (w mld dol.)

\begin{tabular}{|l|c|c|c|c|c|}
\hline \multirow{2}{*}{ Lata } & \multirow{2}{*}{$\begin{array}{c}\text { Saldo } \\
\text { ogółem }\end{array}$} & $\begin{array}{c}\text { Sożyczki } \\
\text { i darowizny }\end{array}$ & $\begin{array}{c}\text { sprzedaż } \\
\text { aktywów } \\
\text { lub zapłata } \\
\text { w złocie }\end{array}$ & $\begin{array}{c}\text { eksport } \\
\text { kapitałów } \\
\text { prywatnych }\end{array}$ & $\begin{array}{c}\text { inne } \\
\text { środki }\end{array}$ \\
\cline { 3 - 6 } & 7,8 & 5,1 & 2,0 & 0,3 & 0,4 \\
1946 & 11,2 & 5,7 & 4,5 & 0,7 & 0,3 \\
\hline
\end{tabular}

Źródło: T. Łychowski, 1954, s. 327.

Zapłata długu w złocie lub sprzedaż aktywów dolarowych przez kraj o ujemnym saldzie bilansu handlowego pokryły ok. 6,5 mld dol. niedoborów na 19 mld dol. dodatniego salda amerykańskiego. W tabeli mamy także informacje o innej metodzie wyrównywania bilansu towarów i usług, a mianowicie o eksporcie kapitałów. Z zestawienia widać jednak wyraźnie, że eksport kapitałów amerykańskich z USA bezpośrednio po wojnie nie przybrał dużych rozmiarów. Należy zdawać sobie sprawę z faktu olbrzymiego wzrostu zysków firm amerykańskich w czasie II wojny światowej. W 1939 r. czysty zysk wszystkich firm amerykańskich wynosił $5946 \mathrm{mln}$ dol. (4,3\% od zaangażowanego kapitału), a w 1943 r. stopa zysku wzrosła do poziomu 8,7\% od kapitału, co stanowiło 12,2 mld dol. Ogólnie zyski firm amerykańskich w okresie $1940-1945$ były szacowane na ok. 59,1 mld dol. (Łychowski, 1954, s. 329)

W latach 1946-1947 w USA dał się odczuć pęd do inwestycji wewnętrznych, uznanych za wygodniejsze i bardziej zyskowne niż inwestycje zagraniczne, ponie- 
waż popyt na rynku wewnętrznym był w tym okresie dostatecznie duży dzięki oszczędnościom poczynionym przez ludność USA w okresie wojny.

Główny ciężar finansowania eksportu amerykańskiego w pierwszych latach powojennych został przerzucony na budżet państwa dzięki uruchomieniu kredytów rządowych. Oligopole, którym były w zasadzie podporządkowane organizacje państwowe, mogły, nie ponosząc ryzyka, ciągnąć korzyści z dostaw towarowych do krajów, którym pożyczki te, stosunkowo niewysoko oprocentowane, były udzielone. Niejednokrotnie procent ten był uzupełniany jednak ciężkimi warunkami, które doprowadziły do podporządkowania sobie państwa pożyczkobiorcy (Yearbook, 1959). Warunki te polegały na odpowiednio dogodnej dla gospodarki USA zmianie ceł, dotyczyły zmian w polityce importowej lub eksportowej, uprawianej przez kraj pożyczkobiorcę i na innych warunkach ograniczających swobodę w podejmowaniu decyzji gospodarczych przez państwo, którego sytuacja zmusiła je do korzystania z kredytów amerykańskich.

Stany Zjednoczone udzielały kredytów państwom alianckim od samego początku wojny. Pierwszym krajem, którego możliwości płatnicze wyczerpały się wkrótce po rozpoczęciu wojny, była Wielka Brytania. Stany Zjednoczone udzieliły jej wówczas kredytu w wysokości $425 \mathrm{mln}$ dol. Rozmiary potrzeb kredytowych innych krajów kapitalistycznych walczących z faszyzmem były jednak tak wielkie, iż wiadomo było z góry, że kredytów wojennych nikt Stanom Zjednoczonym nie będzie w stanie zwrócić (Monthly Bulletin, 1963). Dlatego też sfery rządzące USA zdecydowały się wykorzystać tę niezwykle ciężką sytuację krajów zachodnioeuropejskich i reszty świata kapitalistycznego dla rozpoczęcia ich uzależnienia od USA, aby po wojnie móc „uporządkować” świat zgodnie z interesami wielkich korporacji amerykańskich.

\section{Zmiana pozycji politycznej Stanów Zjednoczonych w świecie w okresie II wojny światowej i po jej zakończeniu}

Atak na Pearl Harbor w grudniu 1941 r. stanowił bezpośrednie zagrożenie strefy wpływów USA na Dalekim Wschodzie. Między przystąpieniem Stanów Zjednoczonych do I wojny światowej a ich przystąpieniem do II wojny światowej występuje podstawowa różnica, która zaważyła na dalszym włączeniu się Ameryki do polityki globalnej. Atakiem na Pearl Harbour Stany Zjednoczone poczuły się bezpośrednio zagrożone i usunięcie tego zagrożenia leżało w ich życiowym interesie. Poparcie udzielone przez Stany pozostałym uczestnikom koalicji antyhitlerowskiej wynikało więc z poczucia zgodności interesów. W trakcie wojny Związek 
Radziecki jako partner w walce z Niemcami i Japonią był cennym sojusznikiem. Nie bez wpływu na stosunek USA do ZSRR był również fakt prowadzenia polityki zagranicznej osobiście przez F.D. Roosevelta, chociaż faktu tego nie należy przeceniać, bo poglądy amerykańskiego prezydenta wynikały po prostu z właściwego rozpoznania interesów państwowych Stanów Zjednoczonych.

Druga wojna światowa ograniczyła liczbę potęg liczących się w skali światowej pod względem militarnym, jak i gospodarczym. Praktycznie zostały tylko dwie: ZSRR i USA, ponieważ siła Wielkiej Brytanii zależała od jedności Commonwealthu, a jej zasoby naturalne i ludzkie były o wiele mniejsze niż wymienionych krajów. Ponadto w czasie wojny Wielka Brytania w sprawach militarnych i gospodarczych jeszcze bardziej uzależniła się od USA. Jej siły funkcjonowały pod wspólnym dowództwem z USA - Combined Chiefs of Staff, istniał również wspólny urząd do rozdziału dostarczanych z USA surowców i żywności.

Dominującą pozycję Stanów Zjednoczonych w gospodarce światowej podkreślała nie tylko wyjątkowo korzystna sytuacja gospodarcza, ale także przewaga na polu militarnym. Już w pierwszych latach po wojnie USA jako jedyne państwo na świecie dysponowały bronią atomową. W czasie wojny został rozbudowany przemysł zbrojeniowy wraz z odpowiednim zapleczem, lotnictwo wojskowe i nowoczesne siły zbrojne. Bazy wojskowe USA znajdowały się w wielu miejscach na świecie, a armia amerykańska była najliczniejsza i najsilniejsza spośród armii wszystkich krajów kapitalistycznych. Dzięki dominującej pozycji gospodarczej i politycznej zwiększały swoje wpływy w krajach wyniszczonych długotrwałą wojną. W całej dotychczasowej historii USA nie zajmowały tak silnej pozycji w gospodarce, polityce i potencjale zbrojeniowym świata kapitalistycznego. Układ sił w państwach kapitalistycznych, ich zależność ekonomiczna od USA, umożliwiły zajęcie przez Stany Zjednoczone pozycji wiodącej w tym systemie i pozwoliły im podporządkować te kraje swoim interesom. Miejsce USA w powojennym świecie i dysponowanie ogromnymi środkami zrodziły chęć narzucenia światu swego rodzaju Pax Americana. Wniosek, że „koniec wojny zastał Amerykę tak silną, że trudno byłoby jej zrezygnować z odpowiedzialności za losy świata” wynikał z przeświadczenia Ameryki o własnej sile (The United States, 1947, s. 47).

Powojenny kształt Europy i świata wyłaniał się już w czasie wojny w wyniku kolejnych konferencji przedstawicieli przede wszystkim USA, ZSRR i Wielkiej Brytanii. Osiągnięcie porozumienia na konferencji w Moskwie w październiku 1943 r. w sprawie utworzenia międzynarodowej organizacji, której celem byłoby zapewnienie pokoju na świecie, określenie granic w Europie, co było m.in. tematem konferencji jałtańskiej, określenie stosunków terytorialnych na Dalekim Wschodzie podczas konferencji w Kairze - to wszystko tworzyło ramy przy- 
szłych stosunków między aliantami. Do tego typu konferencji można zaliczyć konferencję w Poczdamie poświęconą przyszłym losom Niemiec. Jednakże wiele spraw pozostało niezałatwionych i spornych. Śmierć F.D. Roosevelta i przejście prezydentury $\mathrm{w}$ ręce $\mathrm{H}$. Trumana przyśpieszyły również pogłębienie się rozbieżności między USA i ZSRR. Sytuacja polityczna w Europie po II wojnie światowej charakteryzowała się silnym przesunięciem na lewo i wzrostem wpływów partii komunistycznych. Komuniści, występując zdecydowanie przeciwko faszyzmowi, posiadali duży kredyt zaufania w masach pracujących i ten fakt zaważył m.in. na tym, że we Francji w rządzie powojennym znaleźli się również ministrowie będący członkami partii komunistycznej. Ta radykalizacja spowodowała usztywnienie stanowiska socjaldemokracji i przesunięcie partii chadeckich na prawo. Spowodowała również nasilenie się walki politycznej w państwach zachodnich. Dodatkowym czynnikiem wpływającym na niepewność jutra wśród establishmentu w państwach zachodnich było tworzenie się frontów ludowych i „władzy ludowej” w krajach wyzwolonych przez Armię Radziecką. Stany Zjednoczone przez państwa zachodnie były uważane za jedyną siłę, która mogła przeciwstawić się prądom społecznym rozszerzającym swoje wpływy w okresie powojennym. Dał temu wyraz W. Churchill, przemawiając w Stanach Zjednoczonych na Uniwersytecie w Fulton w marcu 1946 r. i wzywając do ścisłych i silnych związków militarnych między Wielką Brytanią i Stanami Zjednoczonymi, które byłyby skierowane swym ostrzem przeciwko Związkowi Radzieckiemu (tzw. Iron Curtain Speech - przemówienie, w którym sformułowano doktrynę „żelaznej kurtyny”). Za praktyczną realizację tego postulatu można uważać przekazanie przez Wielką Brytanię Stanom Zjednoczonym strefy wpływów na Bałkanach, tj. w Grecji i w Turcji. W Grecji wojna domowa, w której prawica znalazła poparcie w wojskach angielskich okupujących ten kraj, stanowiła, zdaniem Wielkiej Brytanii, zagrożenie dla krajów kapitalistycznych. Jednakże Wielka Brytania ze względów ekonomicznych nie była w stanie ponosić kosztów swojej obecności na Bałkanach. Dlatego też 21 lutego 1947 r. poinformowała USA, że nie jest w stanie zapewnić dalszej pomocy militarnej Grecji i Turcji po 31 marca 1947 r. i zwraca się do Stanów Zjednoczonych z prośbą o przejęcie tej roli. Fakt ten J.W. Spanier skomentował w sposób następujący: „21 lutego był dniem historycznym. W tym dniu Wielka Brytania, jedyne mocarstwo, które pozostało w Europie, ogłosiło swój upadek. Wszystkie pozostałe główne siły na świecie upadły - poza Związkiem Radzieckim, który był drugim najpotężniejszym narodem na świecie”. Z faktu tego Stany Zjednoczone wyciągnęły bardzo szybko praktyczne wnioski: 12 marca 1947 r. prezydent Truman wygłosił przemówienie, a następnie Kongres zaakceptował pomoc militarną i gospodarczą dla Grecji i Turcji. Szybkość reakcji Stanów Zjednoczonych świad- 
czyła, że decyzja ta była traktowana jako ukoronowanie długiego okresu umacniania przez USA ich pozycji w świecie (Harper, 1994). Dalsze praktyczne następstwa tej decyzji oraz realizacja dalszej polityki USA zależały w dużej mierze od rozwoju ich sytuacji gospodarczej i politycznej, a także na świecie (Bulletin, 1954).

\section{Sytuacja polityczna i gospodarcza Europy Zachodniej przed i po II wojnie światowej}

Druga wojna w sposób niewątpliwie decydujący zaważyła na utracie przez Europę Zachodnią niezależnej pozycji gospodarczej w stosunku do Stanów Zjednoczonych, ale niekorzystne dla niej trendy w gospodarce światowej wystąpiły na długo przed wojną. Głównym problemem dla Europy Zachodniej było utrzymanie równowagi bilansu płatniczego i handlowego ze światem zewnętrznym, w tym przede wszystkim ze Stanami Zjednoczonymi. Z poniższej tabeli wynika, że gospodarka krajów zachodnioeuropejskich w poważnym stopniu zależała od dostaw zagranicznych, przy czym pewne kluczowe surowce (ropa naftowa, metale nieżelazne, surowce dla przemysłu tekstylnego) były importowane spoza Europy prawie w całości. Europa Zachodnia importowała również 20\% żywności, przy czym w Wielkiej Brytanii aż połowa zapotrzebowania na żywność była pokrywana przez import.

Tabela 4. Udział importu w Produkcie Narodowym Brutto w 1948 r. (w \%)

\begin{tabular}{|l|c|l|c|}
\hline Kraj & Udział & Kraj & Udział \\
\hline Norwegia & 32 & Wielka Brytania & 20 \\
Dania & 30 & Francja & 13 \\
Benelux & 29 & Włochy & 10 \\
Irlandia & 27 & Bizonia & 10 \\
Grecja & 24 & & \\
\hline
\end{tabular}

Źródło: Interim Report on the European Recovery Programme, OEEC, Paris 1948, s. 15.

Zmiany w strukturze handlu światowego, jakie zachodziły w 1. połowie XX w., polegające na tym, iż w światowym obrocie towarowym systematycznie malał udział produktów przemysłowych, miały także niekorzystny charakter dla Europy Zachodniej. W latach 1913-1939 import z terytoriów zamorskich wzrastał, ale eksport z Europy Zachodniej miał tendencję spadkową (eksport towarów przemysłowych głównych krajów rozwiniętych spadł o 25\%). 
Tabela 5. Wielkość handlu światowego $(1913=100)$

\begin{tabular}{|l|c|c|c|c|c|}
\hline Rok & Ogółem & $\begin{array}{c}\text { Art. } \\
\text { przemysłowe } \\
\text { w \% 1913 r. }\end{array}$ & $\begin{array}{c}\text { Surowce } \\
\text { w \% 1913 r. }\end{array}$ & $\begin{array}{c}\text { Art. } \\
\text { przemysłowe } \\
\mathbf{w} \% \text { obrotu } \\
\mathbf{w ~ d a n y m ~ r o k u ~}\end{array}$ & $\begin{array}{c}\text { Surowce } \\
\mathbf{w} \% \text { obrotu } \\
\mathbf{w} \text { danym } \\
\text { roku }\end{array}$ \\
\hline $1876-1886$ & 31,6 & 32,2 & 31,2 & 38,2 & 61,8 \\
$1901-1905$ & 67,9 & 63,2 & 70,7 & 34,8 & 65,2 \\
1913 & 100,0 & 100,0 & 100,0 & 37,5 & 62,5 \\
$1921-1925$ & 82,3 & 76,6 & 85,8 & 34,9 & 65,1 \\
$1926-1930$ & 110,1 & 103,4 & 111,1 & 35,2 & 64,8 \\
$1931-1935$ & 95,3 & 73,5 & 107,2 & 29,7 & 70,3 \\
$1936-1938$ & 107,4 & 92,2 & 116,6 & 32,1 & 67,9 \\
\hline
\end{tabular}

Źródło: Interim Report on the European Recovery Programme, OEEC, Paris 1948, s. 16.

Brak stabilności znajdował odbicie w kryzysach płatniczych i ograniczeniach w handlu i płatnościach. W latach 30. deficyt płatniczy, zwłaszcza z USA (rzędu $750 \mathrm{mln}$ dol.) Europa Zachodnia pokrywała złotem lub dolarami, które otrzymywała z terytoriów zamorskich (zwłaszcza z Azji Południowo-Wschodniej). Utrzymywanie jednak takiego bilansu w dłuższym okresie było dość trudne i wymagało odpowiednich posunięć, takich jak: dewaluacja, ograniczenia ilościowe, wysokie taryfy importowe, co z kolei prowadziło do ustalenia się równowagi przy niskim poziomie aktywności gospodarczej i do dalszego spadku znaczenia gospodarczego Europy Zachodniej. Wraz ze spadkiem eksportu dóbr przemysłowych Europa Zachodnia stawała się coraz bardziej zależna od innych dochodów. W $1938 \mathrm{r}$. $70 \%$ importu było pokrywane eksportem, ok. 20\% było pokrywane z dochodów z inwestycji zagranicznych, a $10 \%$ z opłat za transport morski, z turystyki oraz z innych źródeł.

\section{Sytuacja gospodarcza Europy Zachodniej po II wojnie światowej}

Druga wojna światowa zachwiała ten bilans. Czasowe odcięcie od rynków zagranicznych i utrata niektórych terytoriów zamorskich, zniszczenie tradycyjnych więzi handlowych, przestawienie gospodarki na produkcję wojenną, utrata dużej części tonażu, ograniczenie turystyki i inflacja spowodowały, że trudności w utrzymaniu normalnej wymiany międzynarodowej w pierwszym okresie po II wojnie światowej przybrały na sile i miały większe natężenie niż trudności w samym procesie produkcji (Nowak, 1965a). Okres likwidowania skutków wojny w dziedzinie produkcji był bowiem w tych krajach dosyć krótki i po niedługim 
czasie ich poziom produkcji prawie nie odbiegał od poziomu przedwojennego. Było to możliwe dzięki temu, że wojna w krajach zachodnioeuropejskich spowodowała znaczny wzrost inwestycji niezbędnych do rozwoju produkcji przeznaczonej na cele wojenne. Fakt ten przyczynił się do ekspansji przemysłu ciężkiego, a szczególnie maszynowego, powodując tym samym ograniczenie przemysłu konsumpcyjnego. Po wojnie według bilansu Komisji Ekonomiczno-Gospodarczej ONZ potencjał produkcyjny krajów zachodnioeuropejskich przewyższał poziom przedwojenny, co pozwalało w szybkim tempie nadrobić zaniedbania w zakresie rozwoju przemysłu dóbr konsumpcyjnych, a w szczególności w budownictwie i transporcie (Economic Survey of Europe, 1953, s. 1). Tak więc na przełomie lat 1946 i 1947 kraje Europy Zachodniej, włączając Niemcy Zachodnie i Włochy, osiągnęły 98\% poziomu produkcji przedwojennej (Nowak, 1965, s. 65). Niemcy Zachodnie i Włochy jako państwa pokonane podlegały ograniczeniom produkcyjnym i kontroli państw zwycięskich i dlatego ich powojenny start gospodarczy rozpoczął się z kilkuletnim opóźnieniem.

Europa Zachodnia w przeciwieństwie do Europy Środkowo-Wschodniej w mniejszym stopniu odczuła straty ludnościowe. Zestawienie pokazuje, że mimo strat wojennych liczba ludności w krajach Europy Zachodniej w 1947 r. o ok. 9 mln przewyższała liczbę ludności z końca 1938 r., podczas gdy w całej Europie liczba ludności z 1947 r. była niższa niż w 1938 r. o ok. $9 \mathrm{mln}$.

Tabela 6. Ludność Europy (bez ZSRR; w mln)

\begin{tabular}{|l|c|c|c|c|c|}
\hline Lata & $\begin{array}{c}\text { Europa } \\
\text { Zachodnia } \\
\text { i Północna*) }\end{array}$ & $\begin{array}{c}\text { Europa } \\
\text { Południowa } \\
\text { i Wschodnia**) }\end{array}$ & $\begin{array}{c}\text { Niemcy } \\
\text { i Austria }\end{array}$ & Polska & Razem \\
\hline Koniec 1938 r. & 207,9 & 73,5 & 76,0 & 34,8 & 392,2 \\
Koniec 1947 r. & 217,0 & 67,7 & 74,7 & 23,7 & 383,1 \\
\hline
\end{tabular}

*) Belgia, Dania, Finlandia, Francja, Irlandia, Włochy, Luksemburg, Malta, Holandia, Norwegia, Portugalia, Hiszpania, Szwecja, Szwajcaria, Wielka Brytania, Triest; **) Bułgaria, Czechosłowacja, Grecja, Węgry, Rumunia, Jugosławia.

Źródło: Economic Survey of Europe since the War, Geneva 1953, s. 6.

Z zestawienia wynika, iż po II wojnie światowej Europa Zachodnia znalazła się w korzystniejszej sytuacji w porównaniu z Europą Środkowo-Wschodnią zarówno pod względem posiadanych mocy produkcyjnych, jak i zasobów siły roboczej. Ze względu na dalsze specyficzne znaczenie problemu Niemiec Zachodnich w integracji zachodnioeuropejskiej warto zatrzymać się również nad bliższą charakterystyką sytuacji gospodarczej w tym kraju. 
W końcu wojny straty w kapitale produkcyjnym Niemiec Zachodnich nie były zbyt duże. Najbardziej uprzemysłowione obszary byłej Rzeszy Niemieckiej łącznie z Zagłębiem Ruhry - centrum przemysłu ciężkiego, zostały przejęte przez Niemcy Zachodnie, a wydatki zbrojeniowe przyczyniły się do szybkiego powiększenia kapitału na tym obszarze. Nowo instalowany kapitał był bardziej wydajny i nowocześniejszy niż kapitał z okresu przed II wojną światową, co oznaczało, że przy niższym tempie wzrostu wartości kapitału następował znaczny przyrost zdolności produkcyjnych. Sytuacji w przyroście kapitału nie zmienił także planowany demontaż urządzeń produkcyjnych. Demontaż ten miał wynieść ok. 3 mld DM, ale do końca 1949 r. zdemontowano urządzenia wartości zaledwie 714 mln DM, z których wiele było bezużytecznych dla dalszej produkcji w warunkach pokojowych (Economic Survey of Europe, 1953, s. 7). Niemcy wyłoniły się więc z II wojny światowej z większym potencjałem produkcyjnym niż przed wojną i stały się potencjalnym silnym eksporterem wyrobów przemysłowych i poważnym konkurentem dla innych państw kapitalistycznych (Milward, 1984).

Niemcy Zachodnie znalazły się w korzystnej sytuacji pod względem zasobów siły roboczej dzięki przesiedleniu ludności niemieckiej z obszarów niewchodzących w granice powojennych Niemiec. Uzyskały w ten sposób rezerwy siły roboczej, które odsunęły trudności na rynku pracy o kilka najbliższych lat. W 1939 r. obszar Niemiec Zachodnich zamieszkiwało 39,9 mln osób, w 1946 r. liczba ta wzrosła do 43,9 mln, a w 1950 r. osiągnęła 47,6 mln (Nowak, 1965, s. 68). Dzięki przyrostowi mocy produkcyjnych i potencjału ludnościowego gospodarka niemiecka dokonała w latach 1948-1951 olbrzymiego skoku. Przyjmując 1936 r. za 100, wskaźnik produkcji przemysłowej w tym okresie zwiększył się z 54 do 151. Potencjalne zdolności eksportu dóbr inwestycyjnych pozwoliły Niemcom Zachodnim zastąpić w znacznym stopniu trudny do zrealizowania import ze strefy dolarowej.

Mimo przedstawionych wyżej faktów, w gospodarce światowej dawał się zauważyć stale postępujący proces obniżania się znaczenia Europy Zachodniej na arenie międzynarodowej. Było to spowodowane szeregiem czynników, a jednym z ważniejszych stało się wspomniane zachwianie równowagi bilansów płatniczych tych krajów. Wystarczy porównać wzajemne obroty krajów kapitalistycznych przed wojną i po wojnie, aby stwierdzić gwałtowny procentowy spadek eksportu z Europy Zachodniej w porównaniu z sytuacją przedwojenną. 
Tabela 7. Eksport z krajów kapitalistycznych w latach 1938 i 1946 (w \%)

\begin{tabular}{|l|c|c|}
\hline Kraje & $\mathbf{1 9 3 8}$ & $\mathbf{1 9 4 6}$ \\
\hline USA i Kanada & 18 & 38 \\
Kraje Europy Zachodniej & 45 & 29 \\
\hline
\end{tabular}

Źródło: T. Łychowski, 1954, s. 326.

Nie można również zapomnieć, że po II wojnie światowej z rynków światowych wypadły Niemcy i Japonia. W 1937 r. kraje te wraz z Włochami miały ponad 20\% udziału w eksporcie świata kapitalistycznego, podczas gdy po wojnie udział ten spadł właściwie do zera. Fakt ten w sposób decydujący wpłynął na spadek ogólnych obrotów zachodnioeuropejskich.

W czasie II wojny światowej kraje Europy Zachodniej straciły znaczną część lokat zagranicznych, z których dochody pozwalały im pokrywać nadwyżki importowe z krajów zamorskich. Funkcją lokat zagranicznych było uzyskanie środków płatniczych na pokrycie zobowiązań powstałych z tytułu importu. Oczywiście zwiększenie tych dochodów pozwalało zmniejszyć wysiłek eksportowy dla pokrycia tych zobowiązań (Fisher, 1945). Straty w dochodach z inwestycji zagranicznych w latach 1938-1951 szacowano na ok. $500 \mathrm{mln}$ dol. rocznie. Tak więc w 1951 r. dochody z inwestycji stanowiły wartościowy ekwiwalent ok. 9\% eksportu zachodnioeuropejskiego, podczas gdy w 1938 r. ekwiwalent ten wynosił 32\%. Na obniżającą się pozycję Europy Zachodniej istotny wpływ miało także poważne zadłużenie powstałe w czasie wojny. Poniższa tabela przedstawia zmiany w sytuacji płatniczej Europy w latach 1938-1947.

Tabela 8. Bilanse płatnicze Europy (bez ZSRR) w latach 1938-1947 (w mln dol.)

\begin{tabular}{|l|c|c|c|c|c|c|}
\hline \multirow{2}{*}{ Wyszczególnienie } & \multicolumn{2}{|c|}{ Z USA } & \multicolumn{2}{c|}{$\begin{array}{c}\text { Z resztą } \\
\text { krajów } \\
\text { zamorskich }\end{array}$} & \multicolumn{2}{c|}{ Razem } \\
\cline { 2 - 8 } & $\mathbf{1 9 3 8}$ & $\mathbf{1 9 4 7}$ & $\mathbf{1 9 3 8}$ & $\mathbf{1 9 4 7}$ & $\mathbf{1 9 3 8}$ & $\mathbf{1 9 4 7}$ \\
\hline Import & 1,3 & 5,9 & 4,5 & 7,1 & 5,8 & 13,0 \\
Eksport & 0,6 & 0,9 & 3,1 & 5,2 & 3,7 & 6,1 \\
\hline Bilans handlowy & $-0,7$ & $-0,5$ & $-1,4$ & $-1,9$ & $-2,1$ & $-6,9$ \\
Wpływy z inwestycji zagranicznych netto & $+0,1$ & $+0,1$ & $+1,3$ & $+0,3$ & $+1,4$ & $+0,4$ \\
Wpływy z usług netto & $+0,2$ & $-0,5$ & $-0,5$ & $-0,5$ & $+0,7$ & $-1,0$ \\
\hline Bilans obrotów bieżących & $-0,4$ & $-5,4$ & $+0,4$ & $-2,1$ & - & $-7,5$ \\
\hline
\end{tabular}

Źródło: T. Łychowski, 1954, s. 341-342. 
W latach 1945-1947 wystąpił proces bardzo szybkiego wyczerpywania się rezerw płatniczych krajów europejskich, co obrazuje poniższe zestawienie.

Tabela 9. Wyczerpywanie się rezerw krajów europejskich, które przyjęły propozycje Marshalla (w złocie i w dolarach od lipca 1945 r. do czerwca 1947 r.; w mln dol.)

\begin{tabular}{|l|c|}
\hline Wyszczególnienie & Kwota \\
\hline Zmniejszenie się zapasów w złocie & 1925 \\
Zmniejszenie się zapasów w dolarach & 990 \\
Upłynnienie walorów w dolarach & 215 \\
Krótkoterminowe kredyty handlowe banków amerykańskich & 140 \\
Zakup dolarów w MFW & 50 \\
\hline Razem & 3320 \\
\hline
\end{tabular}

Źródło: Federal Reserve Bulletin, 02.1948, s. 162.

Tabela 10. Wyczerpywanie się rezerw Francji od stycznia 1945 r. do maja 1948 r. (w mln dol.)

\begin{tabular}{|l|c|}
\hline Wyszczególnienie & Kwota \\
\hline Spadek zapasów złota w banku & 1333 \\
Spadek innych wierzytelności publicznych w złocie i dewizach & 667 \\
Rekwizycja zagranicznych walorów & 200 \\
Płynne prywatne wierzytelności w dewizach & 300 \\
\hline Razem & 2500 \\
\hline
\end{tabular}

Źródło: L’Economie, 17.06.1948.

Pożyczka w wysokości 3150 mln dol. udzielona Wielkiej Brytanii przez Stany Zjednoczone w 1945 r. miała powstrzymać pogłębianie się trudności płatniczych aż do 1950 r., ale wyczerpała się już w 1947 r. Jak widać, równowaga osiągana z trudem $\mathrm{w}$ okresie przedwojennym została poważnie zachwiana, wykazując wysokie saldo ujemne. Sytuacja taka była bardzo niekorzystna zarówno dla Europy Zachodniej, jak i dla Stanów Zjednoczonych (European Payment Union, 1950). USA, które w czasie wojny i w latach następnych ogromnie podniosły swoją produkcję, tworząc warunki dla szerokiej ekspansji gospodarczej, były żywo zainteresowane w podtrzymaniu swego eksportu i ewentualnym powiększeniu jego wartości, co w przypadku dalszego pogarszania się stanu finansowego Europy okazałoby się niemożliwe do zrealizowania. Kraje kapitalistyczne nie były w stanie zaspokoić głodu kapitałowego z normalnych źródeł i w normalnych warunkach. Nieustabilizowana sytuacja międzynarodowa, niepewna sytuacja polityczna i trudne położenie gospodarcze tych krajów spowodowały brak zaufania do tych 
państw jako dłużników (Zdziechowski, 1952). Poza tym dawały się odczuć trudności w przypływie kapitałów, a wartość walut tych krajów była nieustabilizowana i niewymienialna.

Z przeprowadzonego wywodu wynika wniosek, że kraje Europy Zachodniej straciły ostatecznie swoją dominującą pozycję w świecie na korzyść Stanów Zjednoczonych (Werner, 1966). Z drugiej strony działania te przyspieszyły również w pewnym stopniu prognozy co do kryzysowego przebiegu koniunktury gospodarczej w 1948 r. i recesyjne ograniczenie importu z krajów Europy Zachodniej, co mogłoby jeszcze bardziej odbić się na sytuacji gospodarczej tych krajów.

\section{Bibliografia:}

Beloff, M. (1963). The United States and the Unity of Europe. London. Bulletin. (1950). Department of State. 17 September.

Bulletin. (1954). Department of State. 27 September.

Camps, M. (1957). Trade Policy and American Leadership. New York: Princeton University.

Economic Survey of Europe in 1961, Part 2: Some Factors in Economic Growth in Europe during the 1950. (1962). Geneva.

Ellsworth, P.T. (1958). The International Economy. New York: McMillan Company.

Feld, W. (1968). The European Common Market and the World. New Jersey.

Ferrell, R.H. (1996). The Truman Era and European Integration. W: F.H. Heller, J.R. Gillingham, The United States and the Integration of Europe. New York: St. Martin's Press.

Fisher, A.G.B. (1945). Economic Progress and Social Security. London: Macmillan \& Co. Ltd. Harper, J.L. (1994). American Visions of Europe. Cambridge: Cambridge University Press. Interim Report on the European Recovery Programme. (1948). Paris: OEEC.

Kamecki, Z., Sołdaczuk, J., Sierpiński, W. (1964). Międzynarodowe Stosunki Ekonomiczne. Warszawa: Państwowe Wydawnictwo Ekonomiczne.

Kwilecki, A. (1969). Idea zjednoczenia Europy. Poznań: Wydawnictwo Poznańskie.

Lundestad, G. (1998). „Empire” by Integration. The United States and European Integration, 1945-1997. Oxford: Oxford University Press.

Łychowski, T. (1954). Zagadnienia obrotu międzynarodowego. Warszawa: PWN.

Milward, A.S. (1984). The Reconstruction of Western Europe 1945-1951. Berkeley: University of California Press.

Morawiecki, W. (1970). Międzynarodowe Organizacje Gospodarcze. Warszawa: SGPiS.

Morison, E.S. (1928). The Oxford History of the United States 1783-1917. Oxford: Oxford University Press.

Nowak, A. (1965). Koncepcje integracji Europy Zachodniej na tle procesów rozwoju ekonomicznego. Poznań: Instytut Zachodni.

Nowak, Z. (1965). Niemiecka Republika Federalna a integracja ekonomiczna Europy Zachodniej. Przeglad Zachodni, 1. 
Spanier, J.W. (1960). American Foreign Policy since World War II. New York: Praeger.

Stebbins, R.P. (1950). The U.S. in World Affairs 1949-1950. New York: Harper\&Brothers. Truman, H.S. (1956). Years of Trial and Hope 1946-1953. London: Holder and Stoughton.

Urwin, D.W. (1995). The Community of Europe. A History of European Integration since 1945. London-New York: Longman.

Van der Beugel, E.W. (1966). From Marshall Plan to Atlantic Partnership. New York: American Elsevier.

Wandycz, P., Frendl, L. (1965). Zjednoczona Europa. Teoria i praktyka. Londyn: Polonia Book Fund.

Werner, A. (1966). Wielka próba sit USA-EWG-NRF. Warszawa: Zachodnia Agencja Prasowa.

Z zagadnień dojrzewania kryzysu gospodarczego w USA. Praca zbiorowa. (1954). Ekonomista, 3.

Zdziechowski, J. (1952). Gtówne zagadnienia ekonomii, gospodarcza i polityczna analiza planu Schumana. Londyn. 